\title{
Analisis Jumlah Pengguna pada Traffic IP- based dengan Multi Criteria Decision Making
}

\author{
MARISA PREMITASARI \\ Institut Teknologi Nasional Bandung, Indonesia \\ Email : marisa@itenas.ac.id
}

Received 20 Oktober 2020 | Revised 15 November 2020| Accepted 30 November 2020

\begin{abstract}
ABSTRAK
Trafik telekomunikasi sudah bermigrasi ke IP-based Traffic. Salah satunya adalah Laboratorium TIK (Teknologi Informasi dan Komunikasi) ITENAS yang menggenerate invarian trafik. Pada penelitian ini, penulis melakukan monitoring pasif dan aktif untuk mendapatkan berbagai invarian trafik. Monitoring pasif didapatkan dari software ISP Moratel dan SOPHOS Firewall. Monitoring aktif dilakukan dengan capture data secara live pada waktu jam sibuk. Invarian trafik yang berhasil di-captured adalah incoming traffic, outgoing traffic, speed, volume, date dan downtime. Jam sibuk diambil berdasarkan dugaan sementara mulai pukul 10.00-16.00. Invarian ini menjadi input dari sistem untuk dijadikan kriteria dan jam sibuk dijadikan atribut. Kriteria dan atribut diolah dengan metoda Multi Criteria Decision Making yaitu SAW (Simple Additive Weighting) dan AHP(Analytical Hierarchy Process). Output dari sistem adalah prediksi jumlah pengguna di jam sibuk dengan skala fuzzy rules. Hasil penelitian menyimpulkan pukul 11.00 AM-12.00 PM adalah jam tersibuk dengan jumlah user terbanyak.
\end{abstract}

Kata kunci: monitoring aktif, monitoring pasif, kriteria, atribut,bobot

\begin{abstract}
Telecommunication traffic has migrated to IP-based traffic. One of the industry is Laboratorium TIK ITENAS (Teknologi Informasi dan Komunikasi) which generates traffic invariant. In this study, the authors conducted passive and active monitoring to obtain various traffic invariance. Passive monitoring were obtained from ISP Moratel software and SOPHOS Firewall. Active monitoring were done by capturing live data during peak hours. Traffic invariance that have been captured consist incoming traffic, outgoing traffic, speed, volume, date and downtime. Busy hours were taken based on personal estimation start from 10.00-16.00. This invariance became the system's input which has been used as criteria and peak hours are used as attributes. Criteria and attributes were processed using the Multi Criteria Decision Making method, namely SAW (Simple Additive Weighting and AHP (Analytical Hierarchy Process). The output of the system is user's number prediction with fuzzy scale. The result concluded that 11.00 AM-12.00 PM is the busiest hours with the most number of users
\end{abstract}

Keywords: active monitoring, passive monitoring, criterion, attributes, weight 


\section{PENDAHULUAN}

Jaringan telekomunikasi saat ini sudah berbasis Internet Protokol, disingkat IP yang menghasilkan berbagai invarian trafik. Sebelum meledaknya era $4 G$ (forth Generation), invarian trafik hanya terdiri dari dua sumber saja, yaitu trafik telephony dan trafik Short Message Services disingkat SMS (Khan, Kumar, Jayakody, \& Liyanage, 2019). Saat dimulainya era $3 G$ (third generation), pemodelan trafik menjadi sangat bervariasi dimana bentuk trafik merupakan kombinasi dari teks, audio dan video (E, Chu, Guo, \& Zhang, 2013). Pada era $4 G$ semua jaringan telekomunikasi menggunakan IP Address sebagai protokol komunikasi .Hal itu berarti bahwa semua divais terhubung dengan internet dan trafiknya adalah trafik data. Protokol-protokol yang mengatur trafik data ini akan mengirim dan mengirimkan kembali sinyal dalam bentuk paket setiap nano detik yang bergantung pada Quality of Services atau disingkat QOS dari sebuah jaringan. Aktivitas trafik data ini akan mempengaruhi pemodelan trafik jaringan sehingga trend-nya berubah perlahan (Haryadi \& Premitasari, 2014).

Untuk mendapatkan data asli dari sebuah jaringan berbasis IP , Seorang network administrator harus melakukan data captured melalui software-software monitoring dimana network administrator dapat me-monitor data dengan dua cara yaitu secara aktif dan secara pasif. Monitoring secara aktif atau disebut pengukuran aktif dilakukan bila user me-monitor data secara langsung (live monitoring) menggunakan sebuah network monitoring software. Monitoring secara pasif dilakukan apabila user $\mathrm{t}$ idak memantau data dan hanya mendapat log reportnya saja dari seorang network administrator yang disebut pengukuran pasif (Mohan, Reddy, \& Kalpana, 2011). Berdasarkan metoda busy hour, user mengambil data bergantung kepada perioda waktu yang dibutuhkan apakah membutuhkan data harian, mingguan, bulanan atau tahunan (Premitasari, 2018).

Banyak metoda yang sudah digunakan untuk peramalan trafik diantaranya adalah metoda dengan pendekatan distribusi matematis yang merupakan metoda konvensional. Berbagai metoda yang berkembang selanjutnya adalah metoda busy hour seperti $A D P H, T C B H$ dan $F D M H$. Ada sebuah metoda yang sering digunakan untuk sistem pendukung keputusan yaitu MCDM atau disingkat Multi Criteria Decision Making yang dapat digunakan untuk meramalkan trafik IP-based. Berbagai tipe MCDM yang sering digunakan yaitu SAW (Simple Additive Weighting), Analytical Hierarchy Process (AHP), ELECTREE, PROMETEE, TOPSIS (Kaliszewski \& Podkopaev, 2016)

Ada banyak invarian trafik yang dihasilkan dari sebuah jaringan berbasis IP. Salah satunya yaitu jumlah pengguna yang mengakses ke jaringan sehingga beban trafik dapat diprediksi. Penelitian ini mengukur trafik IP-Based yang diambil dari jaringan proxy server ITENAS Bandung dimana cara pengukuran dilakukan melalui pengukuran aktif dan pasif. Pengukuran aktif dilakukan dengan memantau trafik secara langsung melalui software monitoring berbayar yaitu PRTG, singkatan dari Paessler Router Traffic Grapher. Pengukuran pasif dilakukan dengan cara mendapat log report dari sotware provider ISP Moratel dan sebuah firewall berbayar bernama SOPHOS. Penelitian ini menggunakan software PRTG dengan batasan 100 sensor dimana hasil dari pengukuran aktif diharapkan dapat mewakili invarian trafik yang mengacu kepada jumlah pengguna(Harli, 2016). Sebagai data perbandingan, penelitian ini juga mengukur secara pasif invarian trafik untuk jumlah pengguna, seperti incoming dan outgoing traffic. Hasil dari semua invarian trafik yang didapat akan dijadikan kriteria input untuk diolah dengan metoda Multi Criteria Decision Making(MCDM). Adapun metoda yang dipakai pada penelitian ini adalah kombinasi dari Metoda $S A W$ dan $A H P$, kependekan dari Simple Additive Weighting dan Analytical Hierarchy Process. Metoda- 
metoda ini akan menghitung invarian trafik yang didapat dari hasil pemantauan untuk diolah sehingga output yang dihasilkan adalah pemeringkatan jam sibuk berdasarkan jumlah pengguna yang mengakses. Pemeringkatan ini sifatnya bisa berupa pembuktian atau peramalan jumlah pengguna tergantung trafik data yang berhasil di-scanning. Tujuan dari penelitian ini adalah mengukur bobot kriteria dari data yang berhasil di-scanning (captured) yang akan menjadi dasar perhitungan jumlah pengguna dilihat dari bobot kriteria terbesar, serta mencari jam sibuk berdasarkan jumlah pengguna.

\section{METODOLOGI PENELITIAN}

Metodologi penelitian yang digunakan mengadopsi dari Decision Support System (DSS) yang mengikuti tiga step (fase), yaitu fase intelligence, fase designed dan fase choice yang dijabarkan sebagai berikut (Nofriansyah, 2015)

\subsection{Fase Intelligence}

Pada awal fase, sistem peramalan trafik ini perlu ditelusuri, dikenali dan diketahui permasalahnya dengan mendefinisikan rumusan masalah tersebut. Sebuah jaringan berbasis IP performanya menjadi tidak optimal karena engineer sulit menganalisis jumlah pengguna yang mengakses ke jaringan kalau hanya melihat jumlah bandwidth saja. Trafik data perlu diolah dengan diverifikasi, diproses dan diuji untuk mengidentifikasikan masalah. Untuk medapatkan rumusan masalah dari sebuah data mentah, penelitian ini menggunakan dua buah tipe pengukuran yaitu pengukuran aktif dan pasif. Pengukuran pasif dilakukan dengan mengambil data berupa format log report dari Laboratorium TIK ITENAS yang berasal dari dua buah sumber informasi yaitu data-captured dari SOPHOS firewall dan software default dari ISP Moratel. Ada banyak data yang disajikan, terutama oleh firewall SOPHOS, dimana Gambar 1 menampilkan incoming dan outgoing traffic dalam satuan Mbps dari bulan oktober sampai November 2019 dalam periode bulanan.

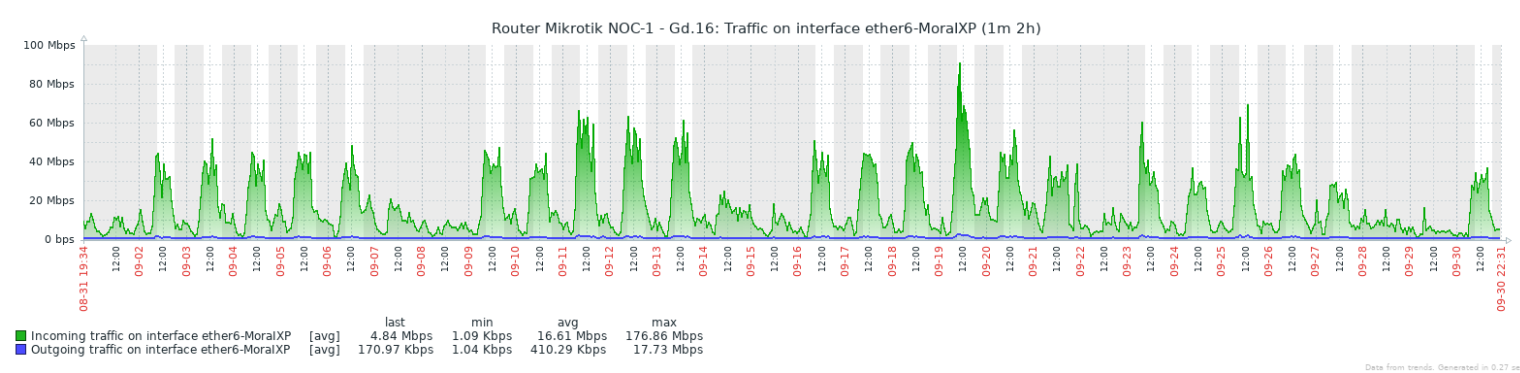

\section{Gambar 1. Data-captured dari SOPHOS Firewall}

Data pada gambar diatas menampilkan sumber data dalam bentuk grafik, dimana warna hijau menunjukkan incoming traffic dan warna biru menunjukkan outgoing traffic dari Router NOC 1 ITENAS yang menjalankan protocol BGP. Data yang tersaji di sumbu $\mathrm{X}$ mengklasifikasikan nilai waktu per 12 jam dan data pada sumbu $Y$ menampilkan bandwidth dalam Mbps.

Data lain yang diambil yaitu log report yang berasal dari software bawaan Internet Service Provider dari Moratell yang diperlihatkan pada Gambar 2 


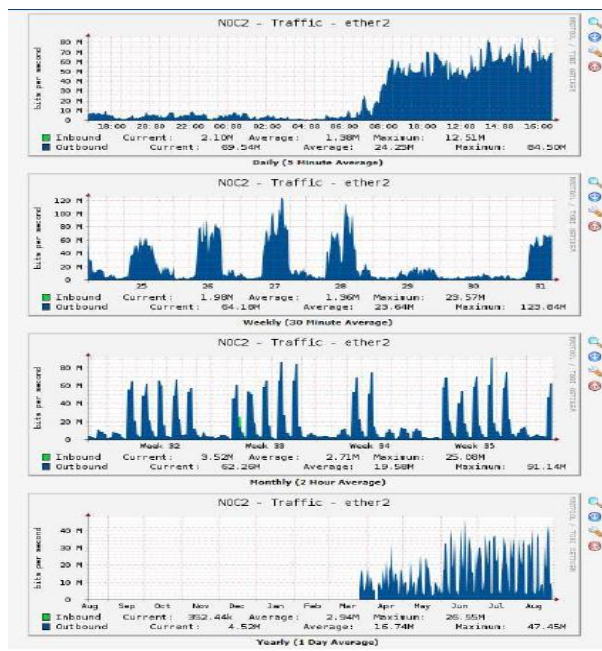

Gambar 2. Log Report Harian, Mingguan, Tahunan dan Bulanan oleh ISP

Untuk pengukuran aktif, data diambil dari perangkat lunak berbayar yaitu PRTG. PRTG dipasang pada laptop dan dijalankan selama rentang waktu satu minggu untuk mengambil data dari router NOC 1 (Network Operating Centre 1) dan NOC 2. Ada banyak tipe dari software PRTG, untuk penelitian ini tipe yang digunakan adalah PRTG Network Monitoring dengan batas 100 sensor. Gambar 3 menampilkan trafik data secara time-series yang dicaptured dari NOC 1 dalam bentuk print screen software.

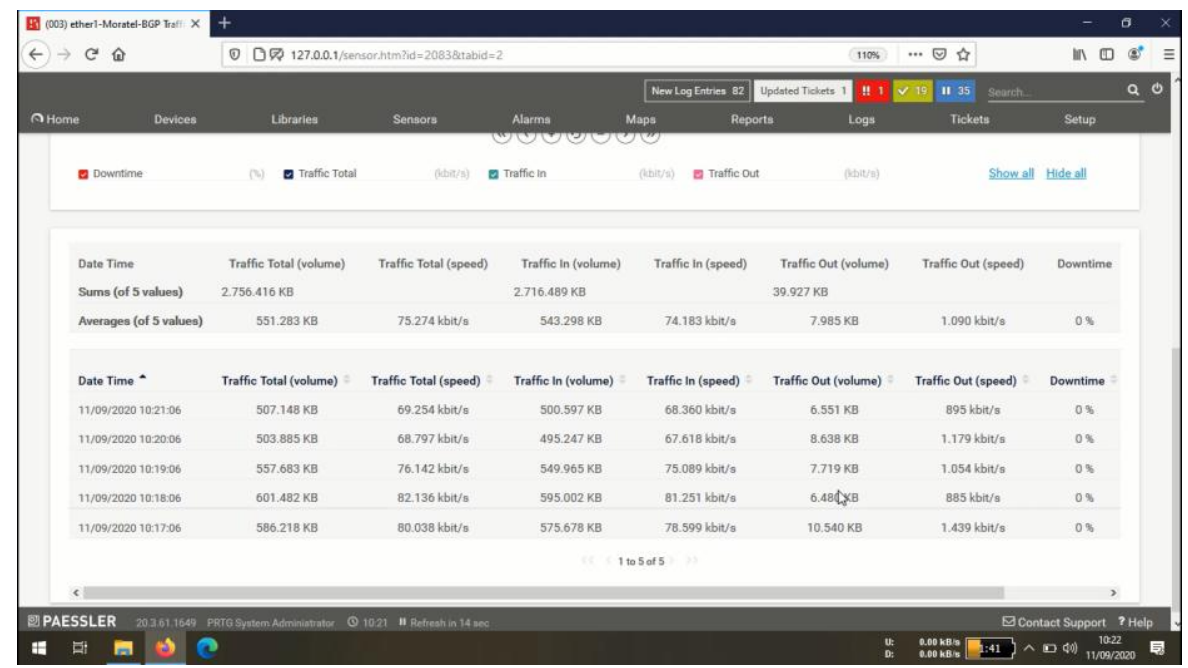

Gambar 3. Trafik Data Secara Time Series oleh PRTG

Ada delapan parameter yang berhasil di-captured oleh perangkat lunak PRTG yaitu date/time, traffic total (volume), traffic total (speed), traffic in (volume), traffic in (speed), traffic out (volume), traffic out (speed) dan downtime. Pada fase selanjutnya, semua data pengukuran pasif dan aktif yang berhasil dikumpulkan, akan dipecah untuk dideteksi dan diklasifikasikan sebagai input sistem dengan pengolahan data yang menggunakan kombinasi perhitungan AHP dan SAW (Pawestri \& Sihwi, 2012)

\subsection{Fase Designed}

Fase ini memecah semua data mentah dari kedua pengukuran menjadi bentuk hirarki tiga level. Level pertama menjelaskan data yang berangkat dari tujuan penelitian ( $g o a)$ level kedua yaitu kriteria dan level ketiga adalah atribut. Hirarki ini disusun berdasarkan metoda 
AHP, dimana Gambar 4 menjelaskan hirarki untuk pengukuran pasif (Dede, Kamalakis, \& Varoutas, 2011)

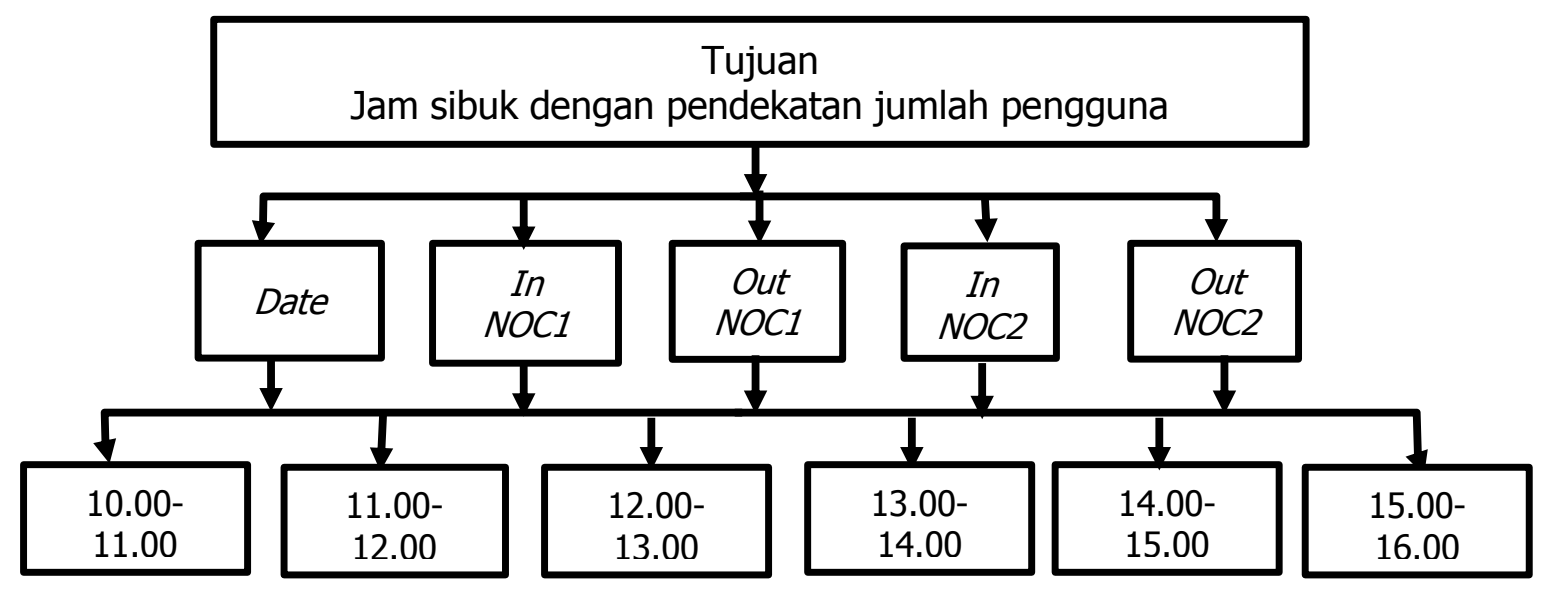

Gambar 4. Hirarki Data untuk Pengukuran Pasif

Tujuan (goa) dari sistem adalah jumlah pengguna dan data yang berhasil di-captured pada pengukuran pasif untuk dijadikan kriteria yaitu Date, In NOC 1, Out NOC 1, In NOC 2 dan Out NOC 2. Date menjelaskan waktu captured data, In NOC 1 dan Out NOC 1 adalah incoming dan Outgoing traffic pada router NOC 1 ,sementara In NOC 2 dan Out NOC 2 menjelaskan incoming dan outgoing traffic pada router NOC 2. Kriteria-kriteira ini memiliki atribut yang sama pada level ketiga, yaitu periode waktu yang diambil pada jam sibuk yaitu jam 10.00-16.00 dan diakumulasikan setiap jam-nya sehingga setiap kriteria memiliki enam atribut seperti diperlihatkan pada Gambar 4 dan 5. Pada Gambar 5 , terdapat delapan kriteria yang dipecah dari tujuan yang sama, yaitu jam sibuk dengan mencari jumlah pengguna. Kriteria-kriteria ini didapat dari pengukuran aktif yang terdiri dari date, total speed, total volume, In volume, In speed, Out volume, out speed dan downtime. Date menjelaskan pukul berapa data diambil, total volume yaitu volume traffic total keseluruhan yang dalam satu periode waktu untuk incoming dan outgoing traffic dengan satuan Kilo Bytes (KB) dan Mega Bytes (MB) , sementara total speed menunjukkan total kecepatan data incoming dan outgoing traffic dalam satuan $\mathrm{kbit/s}$. Volume dan kecepatan setiap incoming dan outgoing traffic ditunjukkan oleh In Volume, In Speed, Out Volume dan Out Speed. Untuk kriteria Downtime, tools ini merekam traffic bila server mengalami downtime.

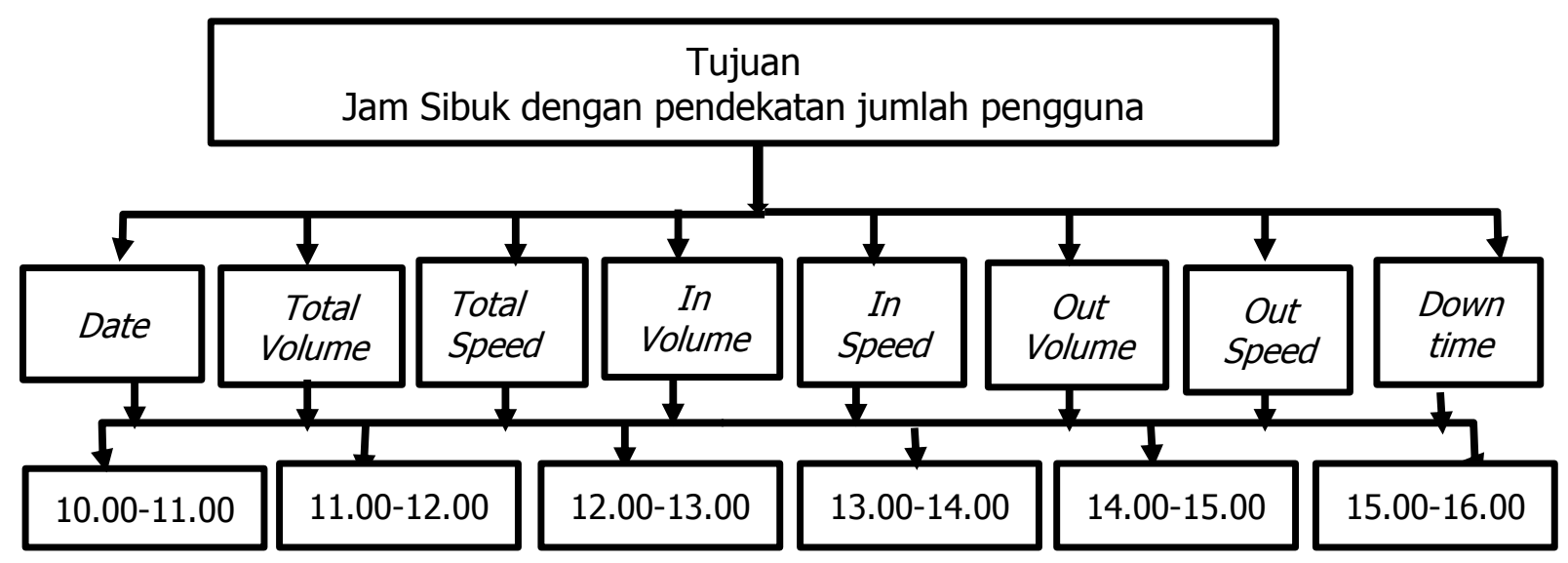

Gambar. 5 Hirarki Data untuk Pengukuran Aktif 
Kriteria pada pengukuran aktif dikodekan sebagai $\mathrm{C} 1-\mathrm{C} 5$, dan kriteria pada pengukuran pasif disimbolkan sebagai C1-C8 (Tabel 1). Setiap kriteria diberi bobot dimana pada pengukuran pasif urutan bobot mulai dari bobot terendah yaitu In NOC 1 dengan bobot 1, In NOC 2 dengan bobot 2, date diberi bobot 3, kemudian In NOC 2 dan Out NOC 2 dengan bobot 4 dan5. Untuk pengukuran aktif urutan bobot dimulai dari downtime dengan bobot 1 , total volume dan in volume diberi bobot 2 dan 3, sementara out volume diberi bobot 4. Date diberi bobot 5, sementara total speed, in speed dan out speed mempunyai bobot 6,7 dan 8 (Tabel 1) .

Tabel 1. Kriteria Bobot untuk Pengukuran Aktif Dan Pasif

\begin{tabular}{|c|c|c|c|c|}
\hline \multirow{2}{*}{ Kode } & \multicolumn{2}{|c|}{ Pasif } & \multicolumn{2}{c|}{ Aktif } \\
\cline { 2 - 5 } & Kriteria & Bobot & Kriteria & Bobot \\
\hline C1 & date & 3 & Date & 5 \\
\hline C2 & In NOC1 & 1 & total volume & 2 \\
\hline C3 & Out NOC1 & 4 & total speed & 6 \\
\hline C4 & In NOC2 & 2 & in volume & 3 \\
\hline C5 & Out NOC2 & 5 & in speed & 7 \\
\hline C6 & $\mathrm{X}$ & $\mathrm{x}$ & out volume & 4 \\
\hline C7 & $\mathrm{X}$ & $\mathrm{X}$ & Out speed & 8 \\
\hline C8 & $\mathrm{x}$ & $\mathrm{X}$ & downtime & 1 \\
\hline
\end{tabular}

Dengan pemberian bobot kriteria secara berurutan ini, sistem akan merangking kriteria yang paling relevan atau mendekati parameter aktivitas pengguna yang mengaju kepada tujuan sistem. Bobot tertinggi menunjukkan kriteria yang paling dekat atau relevan dengan jumlah pengguna yang tertangkap oleh software, sementara bobot terendah memperlihatkan kriteria yang paling tidak relevan dengan jumlah pengguna. Untuk data records, atributatribut digunakan pada sistem ini , dimana Tabel 2 menunjukkan atribut A1- A6 yang berisi data trafik yang tertangkap setiap lima menit dimana seluruh data trafik dibagi menjadi 6 periode yang mengambil waktu jam sibuk dimulai pukul 10 pagi sampai 4 sore dan diakumulasikan setiap jamnya.

Tabel 2. Atribut dari Sistem

\begin{tabular}{|c|c|c|c|c|c|}
\hline A1 & A2 & A3 & A4 & A5 & A6 \\
\hline 10AM-11PM & $11 \mathrm{AM}-12 \mathrm{PM}$ & 12PM-13PM & 13PM-14PM & 14PM-15PM & $15 \mathrm{PM}-16 \mathrm{PM}$ \\
\hline
\end{tabular}

\subsection{Fase Choice}

Penggabungan metoda SAW dan AHP akan diimplementasikan pada fasa ini, dimana langkah-langkah perhitungannya dijelaskan sebagai berikut (Afshari, Mohajed, \& Yusuff, 2010):

a. Bobot kriteria akan diubah ke dalam matrix pairwise comparasion dengan mengikuti Persamaan (1) dan Persamaan (2).

$$
W_{i}=\sum_{i} n(i j)
$$

W adalah bobot dalam baris matrix, dan n menunjukkan jumlah kriteria

$$
A\left(w^{T}\right)=n\left(w^{T}\right)
$$

A kependekan dari atribut, $\mathrm{W}$ menjelaskan nilai bobot dan $\mathrm{T}$ menunjukkan matriks transpose

b. Kriteria diseleksi dan nilai dari setiap alternatif kriteria dijabarkan dalam bentuk skala prioritas. Perhitungan selanjutnya adalah memberi rating yang mungkin untuk setiap kriteria yang terdapat masing-masing atribut dan akan diisi dengan bobot aturan fuzzy, dijelaskan pada Gambar 6 (Nofriansyah, 2015) 


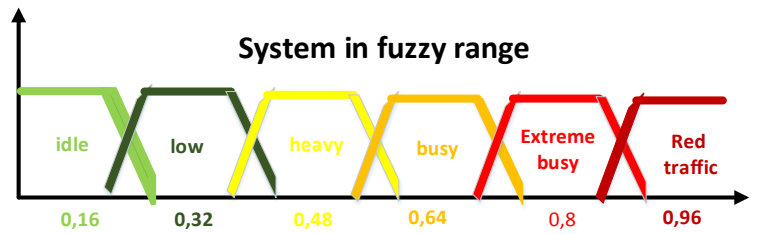

Gambar 6. Fungsi Keanggotan Fuzzy

Ada enam skala fuzzy yang didisain pada sistem ini untuk menggambarkan kepadatan trafik mulai dari yang terendah yaitu idle, low, heavy, busy, extreme busy dan paling tinggi yaitu red traffic. Skala terendah yaitu idle diberi nilai fuzzy 0.16 , diikuti oleh low pada 0.32 , kemudian heavy bernilai 0.48 , busy diberi angka 0.64, Extreme busy bernilai 0.8 dan red traffic yang menggambarkan trafik tertinggi bernilai 0.96 . Nilai dari fungsi keanggotaan fuzzy didapat dari rasio keenam aturan fuzzy yang didapat dari range 0 sampai 1 dengan perbandingan skala $1 / \mathrm{n}$ dikali deret ke- $\mathrm{k}$, dimana $\mathrm{n}$ adalah 6 yang merupakan jumlah kondisi fuzzy seperti pada Persamaan 3.

$$
\sum_{1}^{k}=\frac{k}{n}
$$

Selanjutnya pada Tabel 3 kondisi aturan fuzzy disetarakan dengan besar bandwidth untuk incoming dan outgoing serta tinggi rendahnya speed atau kecepatan data transfer . Nilai bandwidth untuk incoming dan outgoing traffic yang semakin besar menandakan nilai fuzzy yang semakin besar (paling besar red traffic dengan nilai 0,96), sementara Speed yang semakin tinggi akan menunjukkan nilai fuzzy yang semakin kecil (paling kecil idle pada 0,16) dimana bandwidth memiliki range dari $0 G B$ sampai 50 GB sementara speed memiliki range dari 0 Gbps sampai 50 Gbps dimana data ini di-captured secara harian

Tabel 3. Pembagian Range Kriteria

\begin{tabular}{|l|c|c|c|c|}
\hline Skala & Nilai fuzzy & Bandwitdh & Speed & Atribut \\
\hline idle & 0,16 & $0-5 K B$ & 50 Gbps-35Gbps & $11-12$ \\
\hline low & 0,32 & $5 K B-5 M B$ & 5 Gbps-500 Mbps & $10-11$ \\
\hline heavy & 0,48 & $5 M B-50 M B$ & $500 \mathrm{Mbps}-50 \mathrm{Mbps}$ & $12-13$ \\
\hline busy & 0,64 & $50 M B-500 M B$ & $50 \mathrm{Mbps}-5 \mathrm{Mbps}$ & $15-16$ \\
\hline Extreme busy & 0,8 & $500 M B-5 G B$ & $5 \mathrm{Mbps}-5 \mathrm{Kbps}$ & $13-14$ \\
\hline Red traffic & 0,96 & $5 G B-50 \mathrm{~GB}$ & $5 \mathrm{Kbps}-0$ & $14-15$ \\
\hline
\end{tabular}

Data atribut pada Tabel diatas menandakan asumsi jam sibuk yang dihitung di Tabel 4 yaitu bobot dari bandwidth total perminggu. Data pada Tabel 4 diambil dari SOPHOS Firewall ,yang sudah di-captured sebelum tanggal pengukuran pasif dan aktif. Data ini diakumulasikan dari setiap jamnya selama satu bulan. Adapun pengumpulan data dalam bentuk bobot ini akan menjadi acuan nilai fuzzy untuk atribut dimana kondisi idle ada pada jam 11-12, sementara kondisi red traffic di jam 14-15 yang tertuang pada Tabel 3.

\section{Tabel 4. Bobot dari Bandwidth Total Perminggu}

\begin{tabular}{|c|c|c|c|c|c|c|}
\hline minggu/jam & $\mathbf{1 0 - 1 1}$ & $\mathbf{1 1 - 1 2}$ & $\mathbf{1 2 - 1 3}$ & $\mathbf{1 3 - 1 4}$ & $\mathbf{1 4 - 1 5}$ & $\mathbf{1 5 - 1 6}$ \\
\hline Minggu-1 & 2,6 & 2,8 & 2,4 & 4 & 4,4 & 4,8 \\
\hline Minggu-2 & 3,2 & 3 & 2 & 4,6 & 4,6 & 3,6 \\
\hline Minggu-3 & 3 & 3,2 & 3,4 & 4,2 & 3,6 & 3,6 \\
\hline Minggu-4 & 1,8 & 1,2 & 3,8 & 4,8 & 5,8 & 3,6 \\
\hline Jumlah & 10,6 & 10,2 & 11,6 & 17,6 & 18,4 & 15,6 \\
\hline Bobot & 2 & 1 & 3 & 5 & 6 & 4 \\
\hline
\end{tabular}

Akumulasi bandwidth pada Tabel 4 diatas dijumlahkan per-minggu dan menghasilkan jumlah bandwidth yang dibandingkan setiap jamnya, sesuai periode jam sibuk pada 
penelitian ini. Setelah pemberian nilai fuzzy, tahap selanjutnya adalah mengkonversikan data pengukuran pasif dan pengukuran aktif ke dalam nilai fuzzy (Tabel 6 dan Tabel 7) dan merubahnya ke dalam bentuk matriks

c. Tahapan ini menormalisasi kolom pada hasil matriks dari poin (b). cara menormalisasikannya yaitu dengan menghitung nilai performa ternormalisasi yang ditunjukkan oleh Persamaan (4)

$$
r_{i j}=\left\{\begin{array}{l}
\frac{X_{i j}}{\operatorname{Max} X_{i j}} \\
\frac{\operatorname{Min}_{i j}}{X_{i j}}
\end{array}\right.
$$

dimana $r_{i j}$ menunjukkan rating performa performance rating dari matriks pada Tabel 6 dan 7 sementara $X_{i j}$ adalah data matriks berupa nilai fuzzy yang sudah ditentukan pada Tabel 3. Min berarti minimum, yang merupakan atribut cost sebagai beban sistem dalam kasus ini yaitu bandwidth sebagai cost. Simbol Max berarti Maximum, yang merupakan atribut benefit, yaitu keuntungan dari sistem, dimana kriteria speed yang menjadi atribut benefit.

d. Step selanjutnya adalah step terakhir untuk penentuan pemeringkatan jam sibuk dimana nilai preference dihasilkan untuk setiap alternatif atribut dengan cara menjumlahkan perkalian matriks yang dihasilkan dengan nilai bobot yang ditulis pada Persamaan (5)

$$
V_{i}=\sum_{j=1}^{n} w_{j} r_{i j}
$$

dimana $V$ menjelaskan nilai dari setiap alternatif untuk diranking, $W$ yaitu bobot perankingan dan $r$ adalah nilai performa rating (Sahir, Rosmawati, \& Minan, 2017). $V$ kemudian disortir mulai dari nilai $V$ yang tertinggi sampai ke nilai $V$ terendah. (Nofriansyah, 2015)

Untuk validasi hasil pemeringkatan nilai $\mathrm{V}$, sistem ini menggabungkan metoda SAW untuk merangking nilai preference $V$ dan metoda $A H P$ sebagai validasi pemeringkatan dengan cara menghitung nilai $C i$ dan $C R$ yang ditunjukkan oleh Persamaan (6) dan Persamaan (7) sebagai berikut (Yigit,Isik \&Ince, 2013)

$$
C_{i}=\frac{t-n}{n-1}
$$

$\mathbf{t}$ adalah eigen max atau Imax, dan $n$ menjelaskan jumlah atribut

$$
C R=\frac{C I}{I R}
$$

CR singkatan dari Consistency Ratio , CI yaitu Consistency Index dan IR berarti Index Ratio dimana nilai $n$ dijelaskan pada Tabel 5 berikut. 
Tabel 5. Rasio Indeks

\begin{tabular}{|c|c|c|c|c|c|c|c|c|c|c|}
\hline $\mathbf{n}$ & $\mathbf{1}$ & $\mathbf{2}$ & $\mathbf{3}$ & $\mathbf{4}$ & $\mathbf{5}$ & $\mathbf{6}$ & $\mathbf{7}$ & $\mathbf{8}$ & $\mathbf{9}$ & $\mathbf{1 0}$ \\
\hline $\mathrm{IR}$ & 0,00 & 0,00 & 0,58 & 0,9 & 1,12 & 1,24 & 1,32 & 1,41 & 1,45 & 1,49 \\
\hline
\end{tabular}

Nilai $C R$ akan dianggap valid bila hasilnya kurang dari sama dengan 0,1 atau $10 \%$. (Ungkawa, Faruqi, \& Fachrudin, 2019). Gambar 6 menjelaskan metodologi penelitian dalam bentuk diagram alir, yang menjelaskan langkah-langkah penelitian seluruh fase.

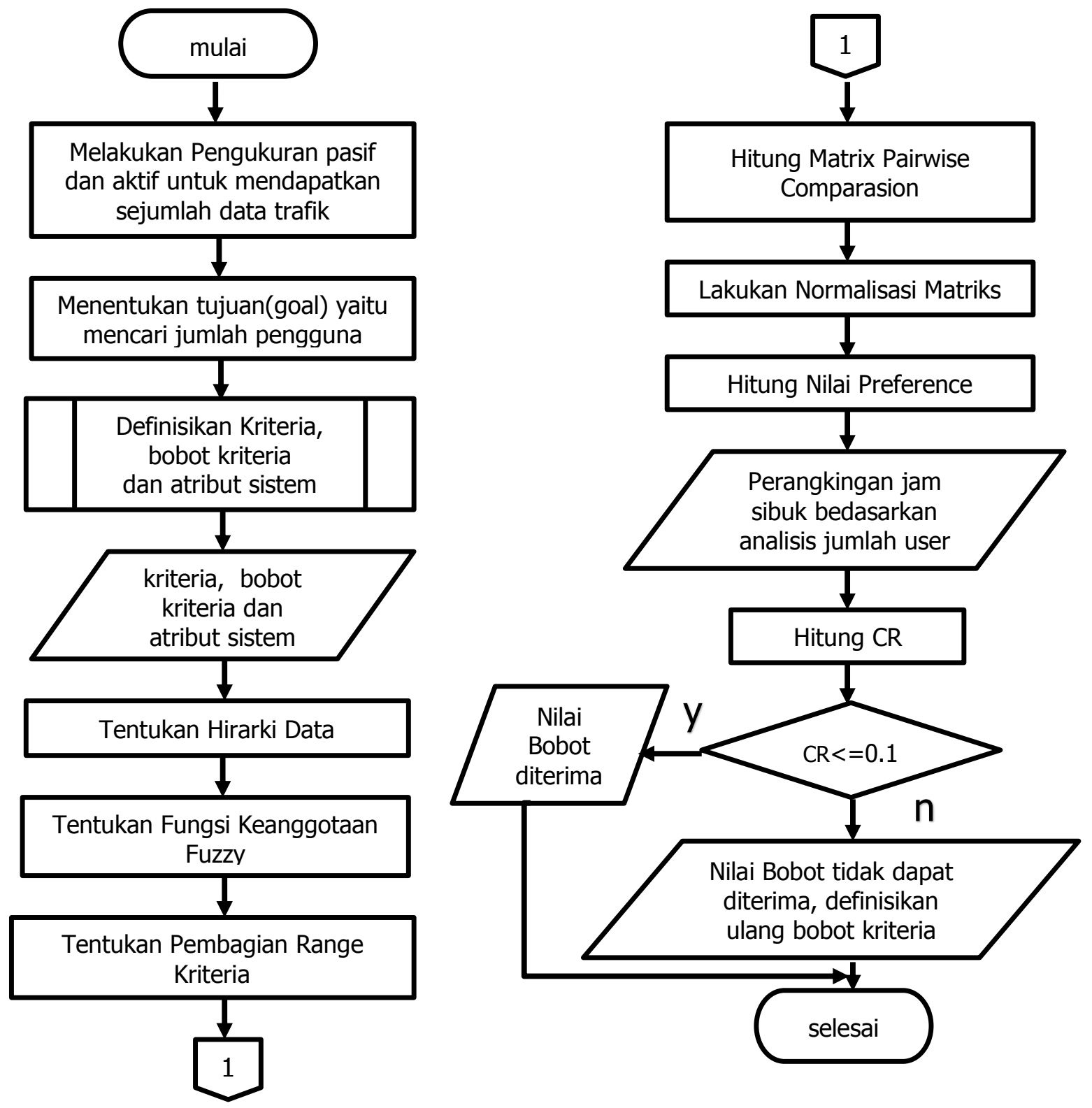

Gambar 6. Diagram Alir Metodologi Penelitian

Perhitungan Multi Criteria Decision System yang menggabungkan metoda Simple Additive Weighting dan Analytical Hierarchy Process ini akan menghasilkan data berupa proses pemeringkatan nilai $\mathrm{V}$ yang dihasilkan mulai dari nilai $\mathrm{V}$ tertinggi sampai terendah sebagai hasil peramalan jumlah pengguna di jam sibuk dan menginterpretasikan bahwa peringkat tertinggi sama dengan jumlah maksimum pengguna begitu juga sebaliknya 


\section{HASIL DAN PEMBAHASAN}

Tabel 6 adalah data pengukuran pasif dan Tabel 7 merupakan data pengukuran aktif yang semuanya dikonversikan ke dalam skala fuzzy .

Tabel 6. Data Akumulasi Pengukuran Pasif

\begin{tabular}{|c|c|c|c|c|c|c|c|c|c|c|}
\hline A & $\mathbf{C 1}$ & $\begin{array}{c}\text { C2 } \\
(\boldsymbol{K B})\end{array}$ & $\begin{array}{c}\text { Nilai } \\
\text { Fuzzy }\end{array}$ & $\begin{array}{c}\text { C3 } \\
(\mathbf{M B})\end{array}$ & $\begin{array}{c}\text { Nilai } \\
\text { Fuzzy }\end{array}$ & $\begin{array}{c}\text { C4 } \\
(\boldsymbol{M B})\end{array}$ & $\begin{array}{c}\text { Nilai } \\
\text { Fuzzy }\end{array}$ & $\begin{array}{c}\text { C5 } \\
(\boldsymbol{M B})\end{array}$ & $\begin{array}{c}\text { Nilai } \\
\text { Fuzzy }\end{array}$ & $\begin{array}{c}\text { Nilai } \\
\text { Fuzzy }\end{array}$ \\
\hline A1 & 2 & 1,29 & 0,16 & 178,5 & 0,64 & 94 & 0,64 & 75 & 0,64 & 0,32 \\
\hline A2 & 1 & 1,24 & 0,16 & 279 & 0,64 & 120.1 & 0,64 & 68.9 & 0,64 & 0,16 \\
\hline A3 & 3 & 1,27 & 0,16 & 236 & 0,64 & 49,4 & 0,48 & 67,6 & 0,64 & 0,48 \\
\hline A4 & 5 & 1,27 & 0,16 & 261,5 & 0,64 & 38,85 & 0,48 & 68,6 & 0,64 & 0,8 \\
\hline A5 & 6 & 1,26 & 0,16 & 263 & 0,64 & 37,1 & 0,48 & 82,8 & 0,64 & 0,96 \\
\hline A6 & 4 & 1,29 & 0,16 & 207,5 & 0,64 & 38,8 & 0,48 & 77,6 & 0,64 & 0,64 \\
\hline
\end{tabular}

Seperti yang sudah dijelaskan pada Tabel 1, C1-C5 pada pengukuran pasif mengkodekan kriteria yang didapat dari pengukuran pasif, dan A1-A6 adalah atribut untuk semua pengukuran (Tabel 2). C1 yaitu date, C2 adalah In NOC 1, C3 yaitu In NOC 2, sementara C4 dan C5 adalah In dan Out untuk NOC2. C2 diakumulasikan dalam satuan KB (Kilo Bytes), C3 -C5 mempunyai satuan MB (Mega Bytes), dan C1 tidak diberi satuan. Untuk atribut , A1 berarti periode jam 10.000-11.00, A2 mengkodekan periode jam 11.00-12.00, begitu seterusnya sampai A6 yang berarti periode 15.00-16.00. Tabel 7 berikut merepresentasikan data pengukuran aktif yang diakumulasikan.

Tabel 7. Data Akumulasi Pengukuran Aktif

\begin{tabular}{|c|c|c|c|c|c|c|c|c|c|c|c|c|c|c|c|c|}
\hline$\overline{\mathbf{A}}$ & $\begin{array}{l}C \\
1\end{array}$ & $\begin{array}{c}\text { Nila } \\
\text { i } \\
\text { Fuz } \\
z y\end{array}$ & $\begin{array}{l}\text { C2 } \\
\text { (G } \\
B)\end{array}$ & $\begin{array}{c}\text { Nila } \\
\text { i } \\
\text { Fuz } \\
\text { zy }\end{array}$ & $\begin{array}{c}\text { C3 } \\
\text { (Gbp } \\
\text { s) }\end{array}$ & $\begin{array}{c}\text { Nila } \\
\text { i } \\
\text { Fuz } \\
\text { zy }\end{array}$ & $\begin{array}{l}\text { C4 } \\
(G \\
B)\end{array}$ & $\begin{array}{c}\text { Nila } \\
\text { i } \\
\text { Fuz } \\
\text { zy }\end{array}$ & $\begin{array}{c}\text { C5 } \\
(M b p \\
s)\end{array}$ & $\begin{array}{c}\text { Nila } \\
\text { i } \\
\text { Fuz } \\
z y\end{array}$ & $\begin{array}{l}\text { C6 } \\
\text { (G } \\
B)\end{array}$ & $\begin{array}{c}\text { Nila } \\
\text { i } \\
\text { Fuz } \\
\text { zy }\end{array}$ & $\begin{array}{c}\text { C7 } \\
(G b p \\
s)\end{array}$ & $\begin{array}{c}\text { Nila } \\
\text { i } \\
\text { Fuz } \\
\text { zy }\end{array}$ & $\begin{array}{l}C \\
8\end{array}$ & $\begin{array}{c}\text { Nila } \\
\text { i } \\
\text { Fuz } \\
z y\end{array}$ \\
\hline $\begin{array}{c}\text { A } \\
1\end{array}$ & 2 & 0,32 & $\begin{array}{c}29 . \\
5\end{array}$ & 0,8 & 0.8 & 0,64 & 2.8 & 0,8 & 83 & 0,64 & 27 & 0,8 & 0.7 & $\begin{array}{c}0,3 \\
2\end{array}$ & 0 & 0,16 \\
\hline $\begin{array}{l}A \\
2\end{array}$ & 1 & 0,16 & 45 & 0,96 & 1.2 & 0,64 & 6.4 & 0,96 & 175 & 0,64 & 39 & 0,8 & 1 & $\begin{array}{c}0,3 \\
2\end{array}$ & 0 & 0,16 \\
\hline $\begin{array}{l}A \\
3\end{array}$ & 3 & 0,48 & 34 & 0,8 & 0.9 & 0,64 & 3.9 & 0,8 & 108 & 0,64 & 30 & 0,8 & 0.8 & $\begin{array}{c}0,3 \\
2\end{array}$ & 0 & 0,16 \\
\hline $\begin{array}{l}A \\
4\end{array}$ & 5 & 0,8 & 52 & 0,96 & 1.4 & 0,64 & 5.2 & 0,96 & 142 & 0,64 & 47 & 0,8 & 1.3 & $\begin{array}{c}0,3 \\
2\end{array}$ & 0 & 0,16 \\
\hline $\begin{array}{l}\text { A } \\
5\end{array}$ & 6 & 0,96 & 55 & 0,96 & 1.5 & 0,64 & $\begin{array}{c}6.1 \\
5\end{array}$ & 0,96 & 168 & 0,64 & 49 & 0,8 & 1.2 & $\begin{array}{c}0,3 \\
2\end{array}$ & 0 & 0,16 \\
\hline $\begin{array}{l}A \\
6\end{array}$ & 4 & 0,64 & 42 & 0,8 & 1.2 & 0,64 & 4.4 & 0,8 & 121 & 0,64 & 38 & 0,8 & 1 & $\begin{array}{c}0,3 \\
2\end{array}$ & 0 & 0,16 \\
\hline
\end{tabular}

C1-C8 menunjukkan kriteria yang berhasil ditangkap dari perangkat lunak PRTG. C1 merupakan date, C2 merupakan total bandwidth dalam satuan GB (Giga Bytes), C3 adalah total speed dalam satuan Gbps (Giga bit per second), C4 adalah Incoming traffic bandwidth (GB), C5 yaitu incoming traffic speed (Mbps), C6 adalah Outgoing traffic bandwidth (GB), C7 yaitu Outgoing traffic speed $(G B)$ dan C8 mengkodekan waktu downtime. Hasil akumulasi untuk semua kriteria pada kedua pengukuran dikonversikan ke dalam nilai fuzzy dan diubah ke dalam matrik $R_{p}$ dan $R_{a}$ sebagai berikut ( $p$ berarti pasif dan $a$ berarti aktif)

$$
\begin{aligned}
& \begin{array}{lllllllllllll}
0,16 & 0,64 & 0,64 & 0,64 & 0,32 & 0,32 & 0,8 & 0,64 & 0,8 & 0,64 & 0,8 & 0,32 & 0,16
\end{array} \\
& \begin{array}{lllllllllllll}
0,16 & 0,64 & 0,64 & 0,64 & 0,16 & 0,16 & 0,96 & 0,64 & 0,96 & 0,64 & 0,8 & 0,32 & 0,16
\end{array} \\
& \begin{array}{lllllllllllll}
0,16 & 0,64 & 0,48 & 0,64 & 0,48 & 0,48 & 0,8 & 0,64 & 0,8 & 0,64 & 0,8 & 0,32 & 0,16
\end{array}
\end{aligned}
$$

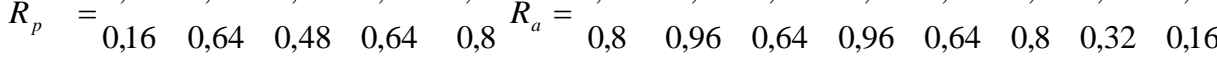

$$
\begin{aligned}
& \begin{array}{llllllllllllll}
0,16 & 0,64 & 0,48 & 0,64 & 0,96 & 0,96 & 0,96 & 0,64 & 0,96 & 0,64 & 0,8 & 0,32 & 0,16
\end{array} \\
& \begin{array}{lllllllllllll}
0,16 & 0,64 & 0,48 & 0,64 & 0,64 & 0,64 & 0,8 & 0,64 & 0,8 & 0,64 & 0,8 & 0,32 & 0,16
\end{array}
\end{aligned}
$$


$R_{p}$ menunjukkan matriks $5 \times 6$ dan $R_{a}$ adalah matriks $8 \times 6$. Untuk menghasilkan matriksmatriks bobot, Tabel 8 dan 9 menghitung matrix pairwise comparasion untuk kedua pengukuran yang menggunakan Persamaan $1 \& 2$.

Tabel 8 Matris Pairwise Comparasion pada Pengukuran Pasif

\begin{tabular}{|c|c|c|c|c|c|c|}
\hline Tujuan & C1 & [2 & [3 & [4 & [5 & Bobat \\
\hline ᄃ1 & 1 & $1 / 4$ & $1 / 2$ & $1 / 5$ & $1 / 3$ & 0,44 \\
\hline$[2$ & 4 & 1 & 2 & $4 / 5$ & $4 / 3$ & 0,11 \\
\hline$[3$ & 2 & $1 / 2$ & 1 & $2 / 5$ & $2 / 3$ & 0,22 \\
\hline$[4$ & 5 & $5 / 4$ & $5 / 2$ & 1 & $5 / 3$ & 0,09 \\
\hline 55 & 3 & $3 / 4$ & $3 / 2$ & $3 / 5$ & 1 & 0,15 \\
\hline Jumlah & 15 & 3,75 & 7,5 & 3 & 5 & 1 \\
\hline
\end{tabular}

Tabel 8 diatas membandingkan kriteria dari pengukuran pasif secara diagonal berdasarkan bobot yang sudah diberikan pada Tabel 1 dimana setiap baris kriteria berisikan bobot yang sudah dibuat rasionya terhadap setiap kolom kriteria dan begitu sebaliknya. Kolom C1 sampai C5 dijumlahkan ratio perbandingannya pada baris Jumlah agar dihasilkan bobot perbandingan pada kolom bobot dimana bila seluruh bobot dijumlahkan bernilai 1 . Dengan perhitungan yang sama, bobot untuk pengukuran aktif diperlihatkan pada Tabel 9.

Tabel 9. Matrix Pairwise Comparasion pada Pengukuran Aktif

\begin{tabular}{|c|c|c|c|c|c|c|c|c|c|}
\hline Kriteria & C1 & C2 & C3 & C4 & C5 & C6 & C7 & C8 & Bobot \\
\hline C1 & 1 & $5 / 2$ & $5 / 6$ & $5 / 3$ & $5 / 7$ & $5 / 4$ & $5 / 8$ & 5 & 0,07 \\
\hline C2 & $2 / 5$ & 1 & $1 / 3$ & $2 / 3$ & $2 / 7$ & $1 / 2$ & $2 / 4$ & 2 & 0,18 \\
\hline C3 & $6 / 5$ & 3 & 1 & 2 & $6 / 7$ & $3 / 2$ & $6 / 8$ & 6 & 0,06 \\
\hline C4 & $3 / 5$ & $3 / 2$ & $3 / 6$ & 1 & $3 / 7$ & $3 / 4$ & $3 / 8$ & 3 & 0,12 \\
\hline C5 & $7 / 5$ & $7 / 2$ & $7 / 6$ & $7 / 3$ & 1 & $7 / 4$ & $7 / 8$ & 7 & 0,05 \\
\hline C6 & $4 / 5$ & 2 & $4 / 6$ & $4 / 3$ & $4 / 7$ & 1 & $4 / 8$ & 4 & 0,09 \\
\hline C7 & $8 / 5$ & 4 & $4 / 3$ & $8 / 3$ & $8 / 7$ & 2 & 1 & 8 & 0,05 \\
\hline C8 & $1 / 5$ & $1 / 2$ & $1 / 6$ & $1 / 3$ & $1 / 7$ & $1 / 4$ & $1 / 8$ & 1 & 0,39 \\
\hline Jumlah & 7,2 & 18 & 6 & 12 & 5,14 & 9 & 4,75 & 36 & 1 \\
\hline
\end{tabular}

Kedua matrix pairwise comparasion ini menghasilkan bobot yang dibutuhkan untuk perhitungan selanjutnya, yaitu mengalikan matriks $R_{p n}$ ( $p n=$ passive normalized) dengan $W_{p}$ , dan $R_{a n}$ (an= active normalized) dengan $W_{a}$

$$
R_{p n}=\left[\begin{array}{ccccc}
1 & 1 & 0,75 & 1 & 0,32 \\
1 & 1 & 0,75 & 1 & 0,16 \\
1 & 1 & 1 & 1 & 0,48 \\
1 & 1 & 1 & 1 & 0,8 \\
1 & 1 & 1 & 1 & 0,96 \\
1 & 1 & 1 & 1 & 0,64
\end{array}\right] W_{p}=\left[\begin{array}{l}
0,44 \\
0,11 \\
0,22 \\
0,09 \\
0,15
\end{array}\right] R_{a n}=\left[\begin{array}{cccccccc}
0,32 & 1 & 1 & 1 & 1 & 1 & 1 & 1 \\
0,16 & 0,83 & 1 & 0,83 & 1 & 1 & 1 & 1 \\
0,48 & 1 & 1 & 1 & 1 & 1 & 1 & 1 \\
0,8 & 0,83 & 1 & 0,83 & 1 & 1 & 1 & 1 \\
0,96 & 0,83 & 1 & 0,83 & 1 & 1 & 1 & 1 \\
0,64 & 1 & 1 & 1 & 1 & 1 & 1 & 1
\end{array}\right] \quad W_{a}=\left[\begin{array}{l}
0,07 \\
0,18 \\
0,06 \\
0,12 \\
0,05 \\
0,09 \\
0,05 \\
0,39
\end{array}\right]
$$

$R_{p n}$ dan $R_{a n}$ didapat dari persamaan 3, dimana matriks $R_{p}$ dan $R_{a}$ dinormalisasi sesuai dengan kriteria yang menjadi benefit atau cost. Kolom 1 sampai kolom 5 dari $R_{p n}$ menandakan C1-C5 pada pengukuran pasif dimana semua kriteria incoming dan outgoing merupakan benefit dan hasil normalisasi angkanya merupakan hasil pembagian dengan nilai maksimum bobot angka pada kolom yang sedang dihitung . Kriteria date tidak dinormalisasikan karena tidak berhubungan dengan beneft ataupun cost. $R_{p n}$ akan dikalikan dengan $W_{p}$, dalam bentuk matriks $5 \times 1$ yang nilainya didapat dari rasio bobot pada Tabel 8 . Untuk pengukuran aktif, Kolom 1 sampai kolom 8 dari $R_{a n}$ menunjukkan C1-C8. Kriteria kriteria dengan sataun GB yaitu C2, C4 dan C6 merupakan kriteria benefit sementara C3, C5 
dan C7 adalah kriteria cost. C1 dan C8 tidak ada hubungannya dengan kriteria benefit ataupun cost. Sama halnya dengan pengukuran pasif, normalisasi data setiap angka untuk pengukuran aktif didapat dari hasil pembagian dengan nilai maximum,bila datanya merupakan kriteria benefit, dan nilai minimum bila data menunjukkan kriteria cost.Selanjutnya $R_{a n}$ akan dikalikan dengan $W_{a}$ yang berbentuk matriks $8 \times 1$ dimana angkanya didapat dari rasio bobot pada Tabel 9 . Matriks $R_{p n}$ setelah dikalikan dengan $W_{p}$ akan menghasilkan nilai Preference (Vi) untuk pengukuran pasif . Begitu juga dengan pengukuran aktif, matriks $R_{a n}$ dikalikan dengan $W_{a}$ menghasilkan nilai Preference (Vi) yang keduanya ditunjukkan pada Tabel 10.

Tabel 10. Nilai Preference

\begin{tabular}{|c|c|c|c|c|c|c|}
\hline \multirow{2}{*}{ Atribut } & \multicolumn{3}{|c|}{ Pasif } & \multicolumn{3}{c|}{ Aktif } \\
\cline { 2 - 7 } & $\mathrm{Vi}$ & Peringkat & Nilai Fuzzy & $\mathrm{Vi}$ & Peringkat & Nilai Fuzzy \\
\hline $\mathrm{A} 1(10-11)$ & $\mathrm{V} 1=0,853$ & 5 & Extremely Busy & $\mathrm{V} 1=0,9624$ & 3 & Heavy \\
\hline $\mathrm{A} 2(11-12)$ & $\mathrm{V} 2=0,829$ & 6 & Red Traffic & $\mathrm{V} 2=0,9002$ & 6 & Red Traffic \\
\hline $\mathrm{A} 3(12-13)$ & $\mathrm{V} 3=0,932$ & 4 & Busy & $\mathrm{V} 3=0,9736$ & 2 & Low \\
\hline $\mathrm{A} 4(13-14)$ & $\mathrm{V} 4=0,98$ & 2 & Low & $\mathrm{V} 4=0,945$ & 5 & Extremely Busy \\
\hline $\mathrm{A} 5(14-15)$ & $\mathrm{V} 5=1,004$ & 1 & Idle & $\mathrm{V} 5=0,9562$ & 4 & Busy \\
\hline $\mathrm{A} 6(15-16)$ & $\mathrm{V} 6=0,956$ & 3 & Heavy & $\mathrm{V} 6=0,9848$ & 1 & Idle \\
\hline
\end{tabular}

Nilai preference tertinggi menjadi nilai trafik terendah di jam sibuk dengan acuan jumlah pengguna, sementara nilai preference terendah menjadi nilai acuan trafik tertinggi. Pada pengukuran pasif, nilai preference tertinggi yaitu 1,004 ada di A5 (V5) pada pukul 14.0015.00, sementara nilai preference terendah yaitu 0.829 ada di A2 (V2) pada jam 11.0012.00. Hasil yang serupa tapi berbeda ditunjukkan oleh pengukuran aktif, dimana periode idle berada di A6 (V6) yaitu pukul 15.00-16.00 dengan nilai preference 0.9848 , sementara nilai preference terendah dengan nilai 0.9002 menunjukkan trafik tertinggi yang samasama berada pada jam 11.00-12.00 . Karena sistem ini menghitung kriteria bandwidth sebagai cost dan speed sebagai benefit, maka atribut dengan nilai preference tertinggi memiliki jumlah user paling sedikit dan atribut dengan nilai preference terendah memiliki jumlah user terbanyak. Untuk pengukuran pasif jumlah pengguna terbanyak ada di jam 1112 siang dan jumlah pengguna paling sedikit ada pada jam 14-15. Pengukuran aktif juga memiliki pengguna terbanyak pada jam 11-12 siang, sementara pengguna paling sedikit ada di jam 15-16,yang periodanya sedikit berbeda satu jam lebih mundur dari pengukuran pasif. Sebagai bentuk validasi dari perangkingan ini Tabel 11 sampai Tabel 13 menunjukkan hasil dari perhitungan metoda $A H P$ untuk pembuktian nilai $C R$, dimana nilai $C R$ akan valid bila hasilnya kurang dari sama dengan 0,1 atau $10 \%$ (Ungkawa et al., 2019). Tahapan perhitungan nilai $C R$ dimulai dari menghitung vektor prioritas seperti yang ditunjukkan pada Tabel 11.

Tabel 11. Vektor Prioritas (Vp)

\begin{tabular}{|c|c|c|c|c|c|c|c|c|}
\hline \multirow{2}{*}{ Kriteria } & \multicolumn{3}{|c|}{ Pasif } & \multicolumn{7}{c|}{ Aktif } \\
\cline { 2 - 9 } & C1-C5 & Bobot & C1-C4 & C5 & C6 & C7 & C8 & Bobot \\
\hline C1 & 0,06 & 0,06 & 0,14 & 0,14 & 0,14 & 0,13 & 0,14 & 0,14 \\
\hline C2 & 0,26 & 0,26 & 0,5 & 0,06 & 0,05 & 0,1 & 0,05 & 0,06 \\
\hline C3 & 0,13 & 0,13 & 0,16 & 0,17 & 0,16 & 0,16 & 0,16 & 0,16 \\
\hline C4 & 0,3 & 0,3 & 0,08 & 0,08 & 0,08 & 0,08 & 0,08 & 0,08 \\
\hline C5 & 0,2 & 0,2 & 0,19 & 0,2 & 0,19 & 0,18 & 0,19 & 0,19 \\
\hline C6 & $\mathrm{X}$ & $\mathrm{X}$ & 0,1 & 0,1 & 0,1 & 0,1 & 0,1 & 0,1 \\
\hline C7 & $\mathrm{X}$ & $\mathrm{X}$ & 0,2 & 0,2 & 0,2 & 0,2 & 0,2 & 0,2 \\
\hline C8 & $\mathrm{X}$ & $\mathrm{X}$ & 0,03 & 0,03 & 0,03 & 0,03 & 0,03 & 0,03 \\
\hline
\end{tabular}

Semua kriteria pada tabel diatas merupakan vektor prioritas yang nilainya dihitung dari rasio kriteria dibagi dengan jumlah kolom dari Tabel 8 untuk pengukuran pasif dan Tabel 9 untuk 
pengukuran aktif. Semua rasio pada pengukuran pasif untuk baris $\mathrm{C} 1$ terhadap $\mathrm{C} 1-\mathrm{C} 5$ adalah 0.06 , untuk C2 adalah 0.26 , C3 bernilai 0.13 , C4 semua barisnya bernilai 0.3 dan C5 bernilai 0.2 sehingga menghasilkan rata-rata bobot yang sama.Pada pengukuran aktif baris C1-C8 bernilai sama terhadap C1-C4, yaitu 0.14 untuk $\mathrm{C} 1,0.5$ untuk C2, 0.16 pada C3, 0.08 pada C4, 0.19 di C5, 0.1 di C6, 0.2 di C7 dan 0.03 untuk C8. Untuk Kolom C5-C6, ratio terhadap kolom C1-C8 mengalami variasi nilai sehingga dihasilkan bobot rata-rata 0.14 pada C1, 0.06 pada C2, 0.16 pada C3, 0.08 di C4, 0.19 di C5, 0.1 di C6, 0.2 di C7 dan 0.03 pada C8. Tabel 12 menghitung nilai weight product yang berasal dari Nilai bobot pada Tabel 8 dan 9 dengan masing- masing nilai vektor prioritas. Sebagai contoh, baris C1 untuk pengukuran pasif pada Tabel 8 dikalikan dengan kolom bobot pengukuran pasif pada vektor prioritas yaitu $(1 \times 0,06)+((1 / 4) \times 0,26)+((1 / 2) \times 0,13)+((1 / 5) \times 0,3)+((1 / 3) \times 0,2)$ dan seterusnya sampai C5. Pada pengukuran aktif, baris $\mathrm{C} 1$ dikalikan dengan kolom vektor prioritas pengukuran aktif

$1 \times 0,14+(5 / 2) \times 0,06+(5 / 6) \times 0,16+(5 / 3) \times 0,08+(5 / 7) \times 0,19+(5 / 4) \times 0,1+(5 / 8) \times 0,2+(5 \times 0,03)$ yaitu dan seterusnya sampai C8 . Nilai-nilai ini menghasilkan weight product pada Tabel 12 ditandai dengan kolom $\boldsymbol{W}_{\boldsymbol{c}} * \mathbf{V p}$ pada kedua pengukuran

Tabel 12. Weight Product

\begin{tabular}{|c|c|c|}
\hline \multirow{2}{*}{ Kriteria } & Pasif & Aktif \\
\cline { 2 - 3 } & $\boldsymbol{W}_{\boldsymbol{c}}{ }^{*} \mathbf{V} \mathbf{p}$ & $\boldsymbol{W}_{\boldsymbol{c}}{ }^{*} \mathbf{V} \boldsymbol{p}$ \\
\hline $\mathrm{C} 1$ & 0,316 & 1,09 \\
\hline $\mathrm{C} 2$ & 1,26 & 0,49 \\
\hline $\mathrm{C} 3$ & 0,63 & 1,31 \\
\hline $\mathrm{C} 4$ & 1,57 & 0,67 \\
\hline $\mathrm{C} 5$ & 0,95 & 1,53 \\
\hline $\mathrm{C} 6$ & $\mathrm{X}$ & 0,87 \\
\hline $\mathrm{C} 7$ & $\mathrm{X}$ & 1,75 \\
\hline $\mathrm{C} 8$ & $\mathrm{X}$ & 0,22 \\
\hline
\end{tabular}

Tabel 13 menunjukkan nilai $C I$ dan $C R$ yang didapat dari membagi nilai weight product dengan vector prioritas yang menjadi input untuk menghitung nilai eigen max (t) sehingga menghasilkan CI dan CR sebagai berikut (Tabel 13)

Tabel 13. Hasil CI dan CR

\begin{tabular}{|c|c|c|c|c|c|c|c|}
\hline \multicolumn{4}{|c|}{ Pasif } & \multicolumn{4}{|c|}{ Aktif } \\
\hline$\frac{\left(W_{c} * V p\right)}{V p}$ & $t$ & $\mathrm{Cl}$ & CR & $\frac{\left(W_{c} * V p\right)}{V p}$ & $t$ & $\mathrm{Cl}$ & CR \\
\hline 5,26 & \multirow{7}{*}{$t=\frac{24,94}{5}$} & \multirow{7}{*}{$C I=\frac{(4,99-5)}{(5-1)}$} & \multirow{7}{*}{$C R=\frac{-0,01}{1,12}$} & 7,79 & \multirow{7}{*}{$t=\frac{65,32}{8}$} & \multirow{7}{*}{$\mathrm{Cl}=\frac{(8,165-8)}{8-1}$} & \multirow{7}{*}{$C R=\frac{0,02}{1,41}$} \\
\hline 4,85 & & & & 8,16 & & & \\
\hline 4,85 & & & & 8,19 & & & \\
\hline 5,23 & & & & 8,38 & & & \\
\hline 4,75 & & & & 8,05 & & & \\
\hline \multirow{4}{*}{$\begin{array}{c}\text { SUM= } \\
24,94\end{array}$} & & & & 8,7 & & & \\
\hline & & & & $\frac{8,75}{73}$ & & & \\
\hline & $t=4,99$ & $\mathrm{Cl}=-0,01$ & & SUM= & $t=8,165$ & $\mathrm{Cl}=0,02$ & CR= \\
\hline & & & $-0,0025$ & 65,32 & & & 0,01 \\
\hline
\end{tabular}

Nilai eigen max $(t)$ didapat dari penjumlahan total nilai weight product dibagi dengan vektor prioritas dan kemudian dibagai dengan jumlah kriteria. Nilai t ini menjadi masukan untuk perhitungan $C I$ dan $C R$ sesuai dengan persamaan (5) dan persamaan (6). Pada pengukuran pasif dihasilkan nilai $t=4,99$ dan menghasilkan nilai $C I=0,01$ dan $C R=-0,0025$. Sementara pada pengukuran aktif, nilai eigen max yang dihasilan adalahh 8,165 sehingga menghasilkan $C I=0,02$ dan $C R=0,01$. Nilai yang menjadi validasi kurang dari sama dengan $10 \%$ adalah nilai CR (Rohandi, Tuloli, \& Jassin, 2018). 


\section{KESIMPULAN}

Hasil perhitungan $C I$ dan $C R$ pada pengukuran aktif dan pasif membuktikan bahwa nilai kriteria pada tabel 1 bersifat valid atau dapat diterima. Pada pengukuran pasif nilai $C I$ yang dihasilkan sebesar 0,01 dan nilai $C R$ sebesar $-0,0025$ dan dapat dibulatkan 0 . Nilai ini membuktikan bahwa kriteria In NOC 1 dengan bobot 1, kriteria In NOC 2 dengan bobot 2, kriteria date dengan bobot 3, kriteria Out NOC 1 dengan bobot 4 dan kriteria Out NOC 2 dengan bobot 5 dapat diterima. Sementara pada pengukuran aktif nilai $C I$ sebesar 0,02 menghasilkan nilai $C R=0,01$ yang artinya bobot kriteria downtime, dengan nilai bobot 1 , Total Volume dengan bobot 2, In Volume dengan bobot 3, Out Volume yang berbobot 4, Date dengan nilai bobot 5, Total Speed dengan bobot 6, In Speed yang berbobot 7 dan Out Speed dengan bobot 8 dapat diterima. Sehingga hasil ini menyimpulkan bahwa jumlah pengguna paling besar dipengaruhi oleh kecepatan upload (Out speed), Kecepatan download ( In Speed) , bandwidth upload (Out NOC 2, Out NOC 1, Out Volume), diikuti date, kemudian bandwidth download (In Volume, In NOC 2, In NOC 1) dan kriteria yang paling tidak mempengaruhi adalah downtime. Hasil penentuan bobot kriteria yang menyimpulkan seberapa besar pengaruhnya terhadap jumlah pengguna ini, dapat berubah bila kriteria yang dimasukkan atau dijadikan acuan tidak sama dengan kriteria yang telah disebutkan tadi. Bila hal ini terjadi , maka sistem perlu menghitung ulang kriteria-kriteria yang telah didapatkan dengan proses yang sama, yaitu proses multicriteria decision making yang mengkombinasikan metoda $S A W$ pada proses perangkingan dan metoda $A H P$ pada pembuktian validasi $C I$ dan $C R$. Pada hasil pemeringkatan dengan metoda $S A W$, sistem ini membuktikan bahwa jam sibuk dengan jumlah pengguna terbanyak ada pada jam 11-12 baik untuk pengukuran pasif dan juga aktif.Urutan jam sibuk dengan pengguna terbanyak untuk pengukuran pasif yaitu 11-12, 10-11, 12-13, 15-16, 13-14 dan pengguna paling sedikit ada di jam 14-15. Untuk pengukuran aktif urutan jam sibuknya adalah 11-12, 13-14,1415,10-11, 12-13 dan pengguna paling sedikit ada di jam 15-16.

\section{UCAPAN TERIMA KASIH}

Penulis mengucapkan terima kasih kepada semua karyawan laboratorium TIK dan LPPM ITENAS yang telah mendanai dan juga ikut membantu penelitian ini. .

\section{DAFTAR PUSTAKA}

Afshari, A., Mohajed, M., \& Yusuff, R. M. (2010). Simple Additive Weighting Approach to Personal Selection Problem. International Journal of Innovation, Management and Technology, 1(5), 511-515. doi:10.7763/IJIMT.2010.V1.89

Dede, G., Kamalakis, T., \& Varoutas, D. (2011). Evaluation of Optical Wireless Technologies in Home Networking : An Analytical Hierarchy Approach. Journal of Optical $\begin{array}{llll}\text { Communication } \quad \text { and } & \text { 850-859. }\end{array}$ doi:https://doi.org/10.1364/JOCN.3.000850 
E, N., Chu, X., Guo, W., \& Zhang, J. (2013). User Data Traffic Analysis For $3 G$ Celullar Networks. Paper presented at the 2013 8th International Conference on Communications and Networking in China (CHINACOM), Guilin,China.

Harli, E. (2016). Pemilihan Network Monitoring System Berdasarkan Kajian Efektifitas Sistem Informasi dengan Pendekatan AHP : Studi Kasus pada "PT.TUV". Jurnal Edukasi dan Penelitian Informatika (JEPIN), 2(1), 64-70. doi:10.26418/jp.v2i1.15555

Haryadi, S., \& Premitasari, M. (2014). Traffic analysis of number of request per user and Volume per Request Hits on IP networks. Paper presented at the 2014 8th International Conference on Telecommunication Systems Services and Applications (TSSA), Kuta,Indonesia.

Kaliszewski, I., \& Podkopaev, D. (2016). Simple additive weighting-A metamodel for multiple criteria decision analysis methods. Expert Systems with Applications, 54, 155-161. doi:10.1016/j.eswa.2016.01.042

Khan, R., Kumar, P., Jayakody, D. N. K., \& Liyanage, M. (2019). A Survey on Security and Privacy of $5 \mathrm{G}$ Technologies: Potential Solutions, Recent Advancements and Future Directions. IEEE Communications Surveys and Tutorials, 22(1), 196-248. doi: 10.1109/COMST.2019.2933899

Mohan, V., Reddy, Y. R. J., \& Kalpana, K. (2011). Active and Passive Network Measurements : A Survey. International Journal of Computer Science and Information Technologies (IJCSIT), 2(4), 1372-1385.

Nofriansyah, D. (2015). Konsep Data Mining Vs Sistem Pendukung Keputusan (1 ed.). Sleman: Deepublish.

Pawestri, D., \& Sihwi, S. W. (2012). Perbandingan Penggunaan Metode AHP dan SAW untuk Sistem Pendukung Keputusan Pemilihan Paket Layanan Internet. ITSMART:Jurnal Teknologi dan Informasi, 1(2), 74-81. doi: https://doi.org/10.20961/itsmart.v1i2.596

Premitasari, M. (2018). Volume Traffic IP-Based dengan Pemodelan Jam Sibuk. MIND, 3(1), $1-14$.

Rohandi, M., Tuloli, M. Y., \& Jassin, R. T. (2018). Priority Determination of Underwater Tourism Site Development in Gorontalo Province using Analytical Hierarchy Process (AHP). Paper presented at the ICIEVE 2017, Manado Indonesia.

Sahir, S. H., Rosmawati, R., \& Minan, K. (2017). Simple Additive Weighting Method to Determining EmployeeSalary Increase Rate. International Journal of Scientific Research in Science, Engineering and Technology(IJSRSET), 3(8), 42-48. 
Yigit,T., Isik, A. H., \& Ince,M. (2013). Web-based Learning Object Selection Software Using Analytical Hierarchy Process. IET Software, 174-183.

Ungkawa, U., Faruqi, R., \& Fachrudin, N. F. (2019). Perbandingan Metode Multifactor Evaluation Process dan Analytical Hierarchy Process. Studi kasus :Promosi Jabatan di Biro Kepegawaian Institut Teknologi Nasional Bandung. MIND Journal, 4(2), 111-121. 